\title{
BELO-SUR-MER AND OTHER INTEGRATED SITES FROM HOLOCENE MADAGASCAR
}

BURNEY*, David A., BURNEY, Lida Pigott, Dept. of Biological Sciences, Fordham Univ., Bronx, NY 10458, USA; GRIFFIN, Will, WRIGHT, Henry T., Museum of Anthropology, Univ. Michigan, Ann Arbor, MI 48109, USA; JAMES, Helen F., MRC NHB 116, National Museum of Nat. Hist., Smithsonian Inst., Washington, DC 20560, USA; JUNGERS, William L., Dept. Anatomical Sciences, SUNY, Stony Brook, NY 11794, USA; MACPHEE, R.D.E., Dept. of Mammalogy, American Museum of Nat. Hist., New York, NY 10024, USA;

RAFAMANTANANTSOA, J.-G., RAKOTONDRAZAFY, T., Service de Paleontologie, Univ. Antananarivo, Antananarivo 101, MADAGASCAR; RAMILISONINA, Musée d'Art et d'Archéologie, Antananarivo 101, MADAGASCAR; WARREN, David, Dept. of Geological Sciences, Brown Univ., Providence, RI 02912, USA; YODER, Anne D., Dept. of Cell \& Molecular Biology., Northwestern Univ. Med. Center, Chicago, IL 60611, USA.

Coordinated multidisciplinary studies of late Pleistocene and Holocene sites in Madagascar have permitted the cross-correlation of paleontological, palynological, and archaeological data concerning the timing, context, and inferred causes of the extinction of the endemic subfossil fauna. Ponds and marshes with pH-buffered sediments have proved especially useful by providing dated stratigraphies containing bones of vertebrates in all size classes, in a sediment matrix preserving pollen, charcoal, and archaeological materials. Landscape-level syntheses indicate a mid-Holocene wet period was followed by increasing aridification beginning ca. 3000 yr B.P. Evidence for human arrival appears about a millennium later, including modified bones of extinct megafauna, increases in microscopic charcoal particles, vegetation changes associated with human modification of the environment, and exotic species introductions.

Recent work at the classic subfossil site of Belo-sur-mer shows particular promise for unraveling the complex natural and human-induced changes of recent millennia. Dating of bone collagen of extinct fauna by AMS ${ }^{14} \mathrm{C}$ demonstrates temporal overlap with the period of human settlement. Pollen stratigraphy indicates vegetation shifts in the Holocene which are reflected in a faunal changeover from arboreal and aquatic taxa to terrestrial and arid-adapted forms. Some extinct taxa may have survived until the last few centuries, suggesting an "extinction window" wider than that predicted by the Blitzkrieg Hypothesis. Although charcoal stratigraphy shows an increase in fire occurrence after human arrival, archaeological survey results suggest that human population density along this part of the SW coast was negligible until ca. $500 \mathrm{yr}$ B.P.

The fortunate coalescence of historical, geomorphological, and geochemical factors permitting the good preservation of many types of evidence in a single interpretable stratigraphy gives sites like Belo-sur-mer considerable potential for integrated-site analysis. A more comprehensive reconstruction of past landscapes in Madagascar is being obtained by combining analysis of this type of site with proxy data from other kinds of sites with a different set of strengths and limitations. Caves are providing paleoecological results in a longer time-frame, including opportunities for U-series dating to $>100 \mathrm{kyr}$ B.P. In order to improve the stratigraphic resolution of our paleoclimatic data down to the annual scale, we are utilizing paleolimnological and palynological analyses of deep crater lakes and dendrochronology of ancient trees with apparently annual rings at several sites in Madagascar. 